\title{
THE ADMISSIBILITY OF "ACQUITTAL EVIDENCE" IN CRIMINAL TRIALS: TOWARD REFORM
}

\author{
Elisabeth McDonald*
}

\begin{abstract}
Recent case law at appellate level in a number of common law jurisdictions has considered the admissibility of "acquittal evidence" - meaning, in the context of this article, either evidence of a defendant's earlier acquittals or evidence on which the acquittals were based. The author argues that the various rulings have resulted in uncertainty and inconsistency and illustrate the difficulty of establishing a single admissibility rule. After analysing the New Zealand case law, the author examines the relevant sections in the proposed Evidence Code, published by the New Zealand Law Commission in 1999, and she concludes by exploring some alternative legislative and judicial resolution of the issues.
\end{abstract}

\section{INTRODUCTION}

Rules concerning the admission of evidence of acquittals in criminal trials have been variously exposed as resting on fine distinctions, ${ }^{1}$ worthy of complete rejection ${ }^{2}$ and as "floating free from any cogent rationale". ${ }^{3}$ Any clear statement of an admissibility rule is seemingly impossible when any such rule must accommodate simultaneously the doctrine of autrefois acquit and the traditional treatment of propensity evidence, while preserving a defendant's right to offer a full defence.

Many evidential decisions of course do require the accommodation of similar contradictions and the relevant inquiries are succinctly encapsulated in the terms probative value and prejudicial

* Senior Lecturer in Law, Victoria University of Wellington. I am grateful for the comments on earlier drafts of this work, provided by my Dean, Matthew Palmer, and by my mentor, Richard Mahoney, University of Otago. I also thank my reviewer, Roger Leng, University of Warwick. I know that my thinking and my writing has benefited from their willingness to share their expertise. I trust I have done justice to their suggestions.

$1 \quad R v Z[2000] 3$ WLR 117, 138 (HL) Lord Hutton.

2 Richard Mahoney "Evidence"[2002] NZ Law Rev 101, 115.

3 Paul Roberts "Acquitted Misconduct Evidence and Double Jeopardy Principles, From Sambasivam to Z" [2000] Crim LR 952, 970. 
effect. Rules contained in appellate decisions concerning the admission of evidence of acquittals however, even when made after consideration of the competing interests of fairness, seem both too particular and too broad in application. As many commentators establish, recent decisions on appeal both in New Zealand and overseas have introduced uncertainty and inconsistency into an area of law that actually requires thoughtful consideration and careful development.

My consideration of the recent New Zealand case law begins with discussion of acquittal evidence offered by the prosecution as propensity evidence against a defendant. In this context, the acquittal evidence being offered is evidence that has formed the basis of a charge for which the defendant has previously been acquitted. The law regarding the use of acquittal evidence as "similar fact" evidence was substantially altered by the Court of Appeal's decision in $R v$ Degnan. ${ }^{4}$ This case answered Robert Lithgow's request ${ }^{5}$ for the Court of Appeal to "choose" between the approach of the House of Lords in $R v Z^{6}$ and that of the Supreme Court of Canada in $R v$ Arp. $^{7}$ My critique of the Court's decision to adopt $R v Z$ includes discussion of the more recent case of $G e e^{8}$ in which the Court of Appeal seemingly appreciates some of the undesirable implications of the approach in Degnan.

I follow this critique with an examination of cases in which the defendant sought to offer acquittal evidence as part of the defence case. In this context the defence usually wishes to offer evidence of the fact that there has been a previous acquittal and will usually not need or wish to offer the evidence considered in the earlier case. Clearly different policy considerations should influence the resolution of these admissibility decisions. The recent cases therefore illustrate the difficulty of establishing a (single) cogent admissibility rule regarding acquittal evidence (whether evidence "of an acquittal" or evidence that "led to an acquittal").

I conclude with my suggestions for possible resolution of the different aspects of these admissibility decisions, both at common law and pursuant to the Law Commission's proposed Evidence Code. ${ }^{9}$

$4 \quad R v$ Degnan [2001] 1 NZLR 280 (CA).

5 Robert Lithgow "Criminal Practice" [2000] NZLJ 293, 295.

$6 \quad R v Z[2000] 3$ WLR 117 (HL).

$7 \quad R v \operatorname{Arp}[1998] 3$ SCR 339.

$8 \quad R v$ Gee [2001] 3 NZLR 729 (CA).

9 New Zealand Law Commission Evidence: Evidence Code and Commentary (NZLC R 55, Vol 2, Wellington, 1999). 


\section{EVIDENCE OF ACQUITTALS AS SIMILAR FACT EVIDENCE: RECENT CASE LAW AND THE DECISION IN DEGNAN}

The cases of Degnan and $R \vee Z$ both raise the issue of the admissibility of "similar fact" evidence when the evidence of earlier similar (sexual) acts resulted in acquittals rather than convictions. In both cases the defendant accepted that the evidence would normally be admissible under similar fact principles, ${ }^{10}$ but objected to the evidence being offered because it had previously resulted in acquittals or, in the case of Ralph Degnan, an acquittal and a stay.

In Degnan the defence argued against admission of the similar fact evidence on the basis that "to lead the evidence led in the earlier cases amounts to an attack of the presumption of innocence in the earlier verdicts". ${ }^{11}$ A stronger statement to this effect was previously made by the Supreme Court of Canada in Grdic v $R:^{12}$

[A]n acquittal is the equivalent to a finding of innocence. ... To reach behind the acquittal, to qualify it, is in effect to introduce the verdict of "not proven", which is not, has never been, and should not be part of our law.

Later in Arp the Supreme Court held that the principle enunciated in Grdic: ${ }^{13}$

is fundamental to our system of justice. It seeks to ensure that an accused need not repeatedly defend himself against the same allegations. Nevertheless, in certain circumstances, the fact of an accused's prior acquittal may have relevance to an ultimate issue in a subsequent trial [for example intent] ... Even if the accused was acquitted of the first charge, the fact that he had been tried on similar charges

... [goes] to his knowledge of wrongdoing irrespective of his guilt on the first charge ... Yet, in most situations, it will be unfair and inappropriate to admit the evidence underlying the prior acquittal as similar fact evidence in a subsequent trial of the same accused.

The Supreme Court in Canada therefore held that only in exceptional circumstances should evidence that resulted in an acquittal be offered in a later trial. ${ }^{14}$ The Court drew a distinction between evidence offered which appears to establish that the defendant is guilty of the earlier offence and evidence that does not establish guilt or goes to a separate issue. In other words, evidence underlying a prior charge may be admissible when it is relevant "irrespective of the outcome of that charge" but inadmissible where the evidence is "relevant only on the assumption of

$10 R v Z$ [2000] 3 WLR 117, 118 (HL) Lord Hope; $R v$ Degnan [2001] 1 NZLR 280, 281 (CA) Tipping J for the Court.

$11 R v$ Degnan, above, 282.

12 Grdic v R [1985] 1 SCR 810, 825 Lamer J.

$13 R v \operatorname{Arp}$ [1998] 3 SCR 339, 382-383 Cory $\mathrm{J}$ for the Court (emphasis added).

14 For a recent critique of this aspect of the decision see Richard Mahoney "Acquittals as Similar Fact Evidence: Another View" (2003) 47 Criminal Law Quarterly 265, 280. 
the accused's guilt". ${ }^{15}$ This distinction was rejected as too fine by the House of Lords in $R v Z$ as part of Lord Hutton's summary of the law: ${ }^{16}$

Provided that a defendant is not placed in double jeopardy ... evidence which is relevant on a subsequent prosecution is not inadmissible because it shows or tends to show that the defendant was, in fact, guilty of an offence of which he had earlier been acquitted ... [A] distinction should not [therefore] be drawn between evidence which shows guilt of an earlier offence of which the defendant had been acquitted and evidence which tends to show guilt of such an offence or which to appears to relate to one distinct issue rather than to the issue of guilt of such an offence.

Previously in $R v$ Arbuckle,${ }^{17}$ the Court of Appeal failed to clarify the New Zealand position on this admissibility question, ${ }^{18}$ in part because the admissibility issue was resolved on other grounds. The Court did, however, gain support for their decision by referring to the risk of unfairness when the fact finder is invited to re-litigate a previous verdict.

In Arbuckle the Court held that evidence offered at a previous trial (which resulted in some convictions and some acquittals) could not be offered in evidence at a later trial so as to defeat the goals of a severance order (which was not appealed by the Crown). The Court supported its conclusion "by considering the problems that could arise in the course of the trial". ${ }^{19}$ The Court commented that offering evidence from the first trial in order to prove fraudulent intent from an earlier time would in effect put into question the acquittal. ${ }^{20}$

In the course of his argument in Arbuckle, Counsel for the Crown had sought to rely on the earlier Court of Appeal case of $R v$ Wilson. ${ }^{21}$ In that case Eichelbaum CJ for the Court accepted that "[similar fact evidence] may be allowed notwithstanding a prior acquittal provided it does not involve or amount to an allegation that the accused committed each element of the offence of which he was previously acquitted". ${ }^{22}$ On the facts of Wilson, the Court was satisfied that the "case can justifiably be viewed as one where considerations of fairness did not demand that the evidence be excluded at a subsequent trial; nor did the prejudicial effect outweigh the probative value". ${ }^{23}$ The

15 Peter Mirfield "Res Judicata Rejected" (2001) 117 LQR 194, 196.

$16 R v Z[2000] 3$ WLR 117, 135 (HL) Lord Hutton (emphasis added).

$17 R v$ Arbuckle [2000] 3 NZLR 49 (CA) Keith J for the Court.

18 See also the comments in Robert Lithgow "Criminal Practice" [2000] NZLJ 293, 295 and in Richard Mahoney "Evidence" [2001] NZ Law Review 85, 90.

$19 R v$ Arbuckle, above, 54.

$20 R v$ Arbuckle, above, 54.

$21 R v$ Wilson [1997] 2 NZLR 161 (CA) Eichelbaum CJ for the Court.

$22 R v$ Wilson, above, 167 (emphasis added).

$23 R v$ Wilson, above, 167. 
particular feature of the case was that a clear distinction could be drawn between the evidence on which the Crown relied for similar fact purposes (possession of stupefying drugs and an intention to use them for sexual purposes), and that required to establish the charge in respect of which the accused had previously been acquitted (rape). In other words, the Court in Wilson accepted that in exercising a judicial discretion to exclude on the grounds of unfairness what is otherwise admissible similar fact evidence, courts should seek guidance from the rule against double jeopardy and the extent to which the evidence requires re-litigation of a previous verdict - in effect reliance on some version of the distinction offered in the Canadian cases.

In Degnan however, the Court of Appeal, after considering both leading overseas authorities, chose to adopt the House of Lords approach in $R v Z$ which rejected those kinds of distinctions - the Court not mentioning their earlier decision in Arbuckle nor disagreeing with Wilson. In fact the Court relied on Wilson to establish a general admissibility rule for similar fact evidence following an acquittal, evidence which may nevertheless be excluded as a matter of discretion. ${ }^{24}$ The way that this discretion to exclude should be exercised was the aspect of the rule which was substantially changed by Degnan. In Degnan the Court declined to uphold the distinction applied in Wilson and the Canadian cases which offers assistance on how the fairness discretion should operate in such cases. ${ }^{25}$ Instead the Court focused on critiquing that distinction by (in part) limiting the meaning and consequences of acquittal for the purpose of later criminal trials.

When considering the alternative authority of $R v \operatorname{Arp}$, the Court of Appeal stated that it found it: 26

difficult to endorse the approach taken in some of the Canadian cases that a verdict of not guilty is the equivalent of a declaration of innocence. That approach risks elevating perceived theory over the realities of criminal practice. In the vast majority of cases a jury, when returning a verdict of not guilty, cannot be taken as saying affirmatively they are satisfied the accused is innocent; what they are really saying is that they are not satisfied beyond reasonable doubt the accused is guilty.

These highlighted words from Degnan are in fact identical to those of North P in Jorgensen $v$ News Media (Auckland) Limited, ${ }^{27}$ which was recently cited as authority for the Law Commission's view of the probative value of acquittals in Evidence: Reform of the Law. ${ }^{28}$ The Law Commission,

$24 R v$ Degnan [2001] 1 NZLR 280, 286 (CA) Tipping J for the Court.

25 "We respectfully agree with the House of Lords that a rule such as that which distinguishes between evidence proving guilt of the earlier allegation and evidence tending to prove such guilt is unsatisfactory, as are the various allied distinctions." Degnan, above, 291.

$26 R v$ Degnan, above, 291 (emphasis added).

27 Jorgensen v News Media (Auckland) Limited [1969] NZLR 961, 978 (CA) North P.

28 New Zealand Law Commission Evidence: Reform of the Law (NZLC R55, Vol 1, Wellington, 1999) 64. 
eighteen months earlier, reached a similar conclusion to that of the House of Lords in $R v Z$ and the Court of Appeal in Degnan, albeit not specifically in the context of the admissibility of similar fact evidence: ${ }^{29}$

In the Commission's view, there is merit in making [an] acquittal admissible as evidence [in criminal trials] ... Admitting the acquittal may give the court the opportunity to hear argument on and take into account the facts leading to the acquittal if they are of significance.

... [T] he Commission considers that there is no need for a specific rule to allow the admission of relevant acquittals because of the fundamental principle in the Code that all relevant evidence is admissible (section 7).

Under the Code, the rule dealing with the admissibility of similar fact evidence is contained in section 45 which essentially codifies the common law position. Evidence admitted under this rule would still be subject to the Code's general exclusion rule (section 8 ). This section provides:

(1) In any proceeding, a judge must exclude evidence if its probative value is outweighed by the risk that the evidence will

(a) have an unfairly prejudicial effect on the outcome of the proceeding; or

(b) needlessly prolong the proceeding.

(2) When determining whether the probative value of the evidence is outweighed by the risk that the evidence will have an unfairly prejudicial effect, the judge must take into account the right of a defendant in a criminal proceeding to offer an effective defence.

The Evidence Code's proposed general exclusion provision (although not referred to by the Court of Appeal) was intended to encompass the kind of exclusion inquiry outlined at the conclusion of Tipping J's judgment for the Court of Appeal in Degnan: ${ }^{30}$

Evidence which otherwise qualifies for admission on similar fact principles is not rendered inadmissible at law by reason of the fact that a previous trial based on that evidence has resulted in an acquittal or a stay of proceedings. Such evidence is admissible, subject to the discretion of the Court to exclude it if its admission would be unfair to the accused, or would otherwise result in an abuse of process. ${ }^{31}$ To obtain such exclusion the accused must be able to point to some particular feature of the case which requires that outcome against the general admissibility of evidence of this kind.

29 New Zealand Law Commission, above, 67.

$30 R v$ Degnan [2001] 1 NZLR 280, 292 (CA) Tipping $\mathrm{J}$ for the Court (emphasis added).

31 The "unfairness" discretion identified by the Court of Appeal is not worded in the same terms as the proposed Code's general exclusion, a point to which I shall return. 
The defendant in Degnan was not, however, able to point to any potential unfairness nor was there any suggestion of abuse of process. The Court of Appeal therefore upheld the District Court Judge's decision to admit the evidence of the two previous complainants, as it was accepted that the evidence was admissible as similar fact evidence. ${ }^{32}$

The decision in Degnan, while defensible on the level of general proposition - all relevant evidence which is not unjustly prejudical should be admissible - fails to adequately describe those situations in which evidence leading to acquittals will result in undue prejudice when offered as evidence in a later trial. The absence of a discussion of the precise application of the admissibility rule set down in Degnan is one of the predominant concerns articulated about this decision. Due to the lack of this discussion, the decision may well operate in practice to undermine at least two important principles which need to be preserved in criminal trials: the rule against double jeopardy and the right of a defendant to offer a defence. The criticisms of Degnan are outlined in the following section.

\section{THE IMPLICATIONS OF DEGNAN: DISCUSSION, CRITIQUE AND GEE}

\section{A Jury Directions and the Discretion to Exclude on the Grounds of Unfairness}

In $R v Z$ and Degnan it was the prosecution who sought to admit the evidence which had given rise to the previous acquittals. In both cases the decision to admit the evidence was based on rules relating to the admissibility of similar fact evidence and the lack of a compelling reason to distinguish between similar fact evidence which resulted in acquittals rather than convictions. In both cases the judicial officers were concerned that the admissibility decision did not offend the principle of "double jeopardy" (also known as autrefois acquit). In other words, the admission of evidence that resulted in a previous acquittal should not be used in a way that would be tantamount to in a finding of guilt for the previously laid charge. The extent to which these precedents will allow this to happen provides the basis for commentators' concern.

Both decisions have attracted criticism because of the apparent limitless application of the admissibility rule they posit. Lord Hutton's statement that: ${ }^{33}$

evidence which is relevant on a subsequent prosecution is not inadmissible because it shows or tends to

show that the defendant was, in fact, guilty of an offence of which he had earlier been acquitted

indicates that relevant evidence of an acquittal is (always) prima facie admissible. In response to the breadth of this conclusion, Colin Tapper stated: ${ }^{34}$

$32 R v$ Degnan, above, 292.

$33 R v Z[2000] 3$ WLR 117, 135 (HL) Lord Hutton.

34 Colin Tapper "Clouded Acquittal" (2001) 117 LQR 1, 1-2. 
It is far from clear whether the implications of this decision were fully appreciated by the House of Lords, either in relation to other aspects of the "similar facts" rule, or in relation to the treatment more generally of acquittals within the criminal justice system.

Although all Tapper's concerns are not significant in the New Zealand context, Richard Mahoney does point to the shared unresolved issue of how juries should be directed to appropriately use "similar fact evidence that questions the conclusion of 'not guilty' reached by an earlier jury". ${ }^{35}$ Degnan offers no guidance to trial judges on how to direct juries as to the use to be made of similar fact evidence which has resulted in a previous acquittal. Mahoney suggests that judges should direct juries not to use evidence if to do so would question an earlier decision. ${ }^{36}$ However, such a direction, if coupled with a similar fact direction, may be simply too complex and confusing for juries to cope with. ${ }^{37}$ Requiring jurors to recognise when an earlier verdict is being called into question is of itself a difficult task for non-lawyers.

Notwithstanding the drafting difficulties, the desirability of juries being appropriately instructed was also recognised by a number of commentators following the decision of the United States Supreme Court in Dowling v United States. ${ }^{38}$ In that case the Supreme Court similarly held that the admission of "prior acquittal evidence" did not breach the constitutional rights of fundamental fairness and the protection offered by the rule against double jeopardy. One commentator argued that the result of the Dowling decision must be that jurors are ${ }^{39}$

explicitly instructed regarding the exact purpose for which the evidence has been admitted and regarding the exact use to which it is to be put. If the jury feels that the evidence fails to satisfy that purpose, they must be required to disregard that evidence ... Without some standard and some guidelines, judges will continue to give juries no more than a simple, unexplained, and often unclear statement of the purposes for which the evidence is offered. The inevitable perils of allowing that evidence will still exist.

The "perils" said to exist in admitting prior acquittal evidence include the prejudicial effect of such evidence, argued to be more prejudicial that evidence of prior convictions. The jury might be "outraged" than the defendant escaped punishment for the earlier crime and was so able to commit

35 Richard Mahoney "Evidence" [2001] NZ Law Rev 85, 91.

36 See also Richard Mahoney "Acquittals as Similar Fact Evidence: Another View" (2003) Criminal Law Quarterly (forthcoming).

37 But see the model jury direction in $R v$ Roberts (1992) 10 CRNZ 172, 177 (CA) Gault J for the Court.

38 Dowling $v$ United States (1990) 493 US 342. For an earlier annotation of the United States state and federal cases on point see Christopher Bello "Admissibility of Evidence as to Other Offense as Affected by Defendant's Acquittal of that Offense" (1983) 25 ALR (4th) 934.

39 Robert Goldstein "Double Jeopardy, Due Process, and Evidence from Prior Acquittals" (1990) 13 Harvard Jl of Pub Policy 1027, 1036-7. 
further criminal acts. An acquittal also arguably lessens the probative value of the evidence offered because it is less likely that the act occurred. ${ }^{40}$

These arguments did not, however, prevent the Court in Degnan finding that there was no particular unfairness outweighing the case for "general admissibility of evidence of this kind."41 The Court of Appeal in Degnan opted to follow $R v Z$ as to the general admissibility rule but, even having done this, it was still open to the Court to exclude the evidence as a matter of the unfairness discretion the Court was careful to preserve. ${ }^{42}$ The two cases can be distinguished on their facts.

In $R \vee Z$ the defendant had been convicted once previously of rape (in similar circumstances) and acquitted three times. In Degnan, the defendant had been acquitted once and the second prosecution had been stayed after two juries had failed to agree on a verdict. In other words, he could well be an "entirely innocent" defendant. I have no particular argument with the Court's decision that "the same [admissibility rule] must apply, if anything more strongly, in the case of a stay", ${ }^{43}$ but there is surely a strong argument for excluding the evidence on the grounds of unfairness when in neither previous case it led to a conviction. In other words, the Court of Appeal in Degnan could have elected to accept the general admissibility rule proposed in $R v Z$ but nevertheless excluded the evidence on the particular facts of Degnan. The need for considered exercise of the fairness discretion is a point to which I will return. Fairness is of course also at issue when the evidence operates to allow re-litigation of the earlier not-guilty vedicts.

\section{$B$ The Potential for Re-litigation and the Case of Gee}

As noted earlier, Mahoney also criticises the Degnan decision for the consequential unlimited ability of the prosecution to re-litigate the previous verdicts. ${ }^{44}$ Although the Court of Appeal and House of Lords were careful to preserve the rule against double jeopardy, as a result of $R v Z$ the distinction between evidence offered which may establish prior guilt and that which does not has been dispensed with. This means that once the evidence is admitted (subject to jury directions, if any) there is no particular limit as to its use and its admission may actually encourage a jury to examine the validity of the previous verdict. As Mahoney points out, there is nothing in either case to guide later courts on how to prevent "relitigation of decided issues". ${ }^{45}$ Mahoney argues that the alibi hypothetical from $R v Z$ referred to in Degnan, which is offered as an example of when such

40 Cynthia Randall "Acquittals in Jeopardy: Criminal Collateral Estoppel and the Use of Acquitted Act Evidence" (1992) 141 U Pa L Rev 283, 303.

$41 \quad R v$ Degnan [2001] 1 NZLR 280, 292 (CA) Tipping J for the Court.

$42 R v$ Degnan, above, 292.

$43 R v$ Degnan, above, 292.

44 Richard Mahoney "Evidence" [2001] NZ Law Rev 85, 91.

45 Mahoney, above, 91. 
evidence would not be admissible, is merely an "idiosyncratic example" which actually exemplifies the seemingly limitless possibilities for relitigation. ${ }^{46}$

At the conclusion of his judgment in $R v Z$, Lord Hobhouse discusses the situation of an accused who spends time and money procuring alibi witnesses to successfully defend a previous rape charge. ${ }^{47}$ Tipping $\mathrm{J}$, in his judgment for the Court of Appeal, concludes that "[i]t might then be unfair to the accused to seek to lead evidence from the first complainant, in spite of her evidence otherwise qualifying on similar fact principles". ${ }^{48}$ In other words, if the evidence does seem to reopen an issue that has clearly been decided it would be unfair to admit the evidence. The extent of this exception to Degnan will be discussed further when considering the appropriate scope of the decision.

Commentators' concern about the scope for re-litigation when evidence leading to an acquittal is introduced in a later trial - re-litigation amounting to a breach of the rule again double jeopardy was echoed by the Court of Appeal itself in the more recent case of Gee, ${ }^{49}$ in which Degnan was purportedly distinguished.

Daniel Gee and a co-accused (Sinclair) were tried together on two charges of burglary. At trial, the District Court judge discharged Sinclair on the first count for want of evidence and the jury found Gee not guilty on the first count. Both the accused were found guilty on the second count. Gee successfully appealed his conviction on the basis of misdirection but the Court went on to "consider the wider issues which arise and which are of some general significance". ${ }^{50}$ The Court recognised that the crucial issue at the retrial (which in the event did not occur) "will be whether, and if so on what basis, the evidence in relation to the first count on which Mr Gee was acquitted can be considered by the jury in relation to the second ... count". ${ }^{51}$ This issue was resolved relatively easily, in part because of the decision the Court had taken about the standard of proof.

The first part of the judgment in Gee considered the standard of proof in similar fact cases where identity is at issue. ${ }^{52}$ The Court concluded that trial Judges should apply the "criminal standard of proof at the first or threshold step". ${ }^{53}$ In other words, the prosecution must prove the accused's

46 Mahoney, above, 91.

$47 R v Z[2000] 3$ WLR 117, 139 (HL) Lord Hobhouse.

$48 R v$ Degnan [2001] 1 NZLR 280, 291 (CA) Tipping J for the Court.

$49 R v$ Gee [2001] 3 NZLR 729 (CA) Tipping J for the Court.

$50 \quad R v$ Gee, above, 730.

$51 R v$ Gee, above, 732.

52 For valuable discussion of this part of the judgment see further Richard Mahoney "Evidence" [2002] NZ Law Rev 102-110.

$53 R v$ Gee, above, 738 (CA) Tipping $\mathrm{J}$ for the Court. 
commission of the similar act beyond reasonable doubt. The similar act in Gee was the commission of the first charge of burglary of which Gee was acquitted.

The Court of Appeal was well aware that requiring proof of the previous charge beyond reasonable doubt before the jury could consider using the (acquittal) evidence as similar fact evidence would "invite a finding in conflict with that of the first jury ... [and] ... the law should [not] countenance such a situation". ${ }^{54}$ Despite this compelling argument of seemingly broad application, the Court then attempted to preserve the principle in Degnan by distinguishing the facts of Gee and establishing identification cases as an exception to Degnan.

As Mahoney rightly points out, inviting "a finding in conflict with that of the first jury"55

... will occur in every case in which similar fact evidence that has previously formed the basis of an acquittal is admitted to help prove the charge in question - whether the issue is the identity of the offender or the occurrence of an offence.

To the extent that Degnan operates as a "declaration of open season for the prosecution to relitigate previous verdicts of acquittal", 56 it is therefore a precedent of some concern.

The decision in Degnan was however welcomed by the Law Commission in its more recent related report: Acquittal Following Perversion of the Course of Justice. ${ }^{57}$ As stated earlier, the Commission's draft Evidence Code envisions that evidence of acquittals may be admitted and the accompanying Report suggests that "[a]dmitting the acquittal may give the court the opportunity to hear argument on and take into account the facts leading to the acquittal if they are of significance", 58 indicating no particular concern with the possibility of re-litigation.

Concern about re-litigation has, however, arisen in cases dealing with evidence of acquittals lead by the defendant but not offered as character or propensity evidence. These cases, as with those concerning similar fact evidence, also highlight the importance of appropriate jury directions as well as the importance of a general discretion to exclude. I now consider these cases in more detail.

$54 \quad R v$ Gee, above, 739

55 Mahoney, above, 113.

56 Richard Mahoney "Evidence" [2001] NZ Law Rev 85, 91.

57 New Zealand Law Commission Acquittal Following Perversion of the Course of Justice (NZLC, R70, Wellington, 2001) vii.

58 New Zealand Law Commission Evidence: Reform of the Law (NZLC R55, Vol 1, Wellington, 1999$) 67$. 


\section{ACQUITTAL EVIDENCE OFFERED BY THE DEFENDANT IN THE CONTEXT OF A RE-TRIAL}

\section{A Evidence Offered to Disprove an Element of the Offence: a pre-Degnan decision}

In his oral judgment $R v B^{59}$ delivered six months before the decision in $R v Z$, Baragwanath $\mathrm{J}$ considered the defendant's application to offer evidence of his acquittals on 11 counts of "various forms of sexual misconduct" at the re-trial for Count 12. His Honour's starting point was similar to the approach taken in Degnan: relevant evidence is admissible unless excluded by some rule of law or judicial discretion. ${ }^{60}$ Barawanath $\mathrm{J}$ went on to make a general statement concerning the admissibility of evidence offered by a defendant in a criminal trial: "In the case of relevant evidence sought to be introduced by an accused the Court will be very slow to disallow it on policy grounds". 61

This statement is also consistent with the view of the Law Commission in section 8 of the proposed Evidence Code (set out previously): in making admissibility decisions the judge must give consideration to the rights of an accused to mount a defence. In $R v B$ the defendant argued that the fact of the acquittals were relevant to the complainant's credibility - seemingly to avoid the possibility that the acquittals would be excluded if offered to prove innocence. This argument, in the context of a rape trial when credibility issues are critical, is still, I believe, somewhat at odds with the Court of Appeal's later view in Degnan.

An acquittal cannot be taken as meaning the jury believes the defendant is innocent (that is, the complainant is lying or mistaken) - "what [the jury is] really saying is that they are not satisfied beyond reasonable doubt the accused is guilty". ${ }^{62}$ Baragwanath $\mathrm{J}$ made a similar point in $R v B$, also in response to the Canadian decisions: "The dicta as to 'innocence' go too far if they are to be applied for all purposes including entitlement to costs and compensation". ${ }^{63}$ His Honour was therefore of the view that an acquittal should not be synonymous with innocence and so it should logically follow that evidence which led to an earlier acquittal may be relevant to establish (or not) the defendant's guilt of another charge. However, on the particular facts of $R v B$, and in response to the defendant's argument, the judge focussed on whether evidence of the fact of previous acquittals could be admitted as sufficiently relevant to an assessment of the complainant's credibility. On this point Baragwanath J stated: ${ }^{64}$

\footnotetext{
$59 R \cup B(1$ November 1999) High Court Auckland T 991037, Baragwanath J.

$60 R v$ Degnan [2001] 1 NZLR 280, 285 (CA) Tipping J for the Court.

$61 R v B$, above, 2.

$62 R v$ Degnan, above, 291.

$63 R \vee B$, above, 4.

$64 R v B$, above, 8 .
} 
On a challenge to credibility the Court will ordinarily give a fair measure of latitude to defence counsel. As a matter of logic it can be argued that the acquittals could have some relevance which is normally enough for the material to be put before the jury. It can hardly be said that the evidence is not at all relevant as going to credibility, the point is rather that its relevance is limited ...

In this case the jury did not acquit on Count 12. It is the only count on which there was corroborative evidence. There is no positive reason to suspect the acquittals are to be characterised as involving the concoction of a perjured count by the complainant rather than the jury not being satisfied to the level required by law, faced with the direction as to onus and standard of proof and a conflict of evidence between the complainant and the accused. ${ }^{65}$

The Judge was also concerned that once the evidence of the acquittals was admitted to attack the complainant's credibility, the prosecution would be entitled to bolster her credibility by traversing the evidence offered in relation to the other 11 counts, the accused's response and the jury's response to the evidence. Baragwanath $\mathrm{J}$ was mindful of the undesirable consequences of such an outcome discussed by Lord Lane CJ in $R v H:{ }^{66}$ deflection of the jury's attention from the issues and evidence before them and speculation as to what motivated the previous jury.

Despite acknowledging arguments to exclude the evidence of the fact of the acquittals, Baragwanath J eventually chose to follow the approach in $R v H$. In that case Lord Lane CJ felt the interests of justice would be served by instructing the jury not to speculate on the earlier hearing but to acknowledge the existence of a previous trial. Baragwanath $\mathrm{J}$ went further in his proposed direction by advising the jury how the other 11 counts differed from Count 12 (that is, absence of corroborating evidence). His Honour freely admitted that this result "may be criticised as failing to elect between incompatible choices - either admit as relevant or exclude as irrelevant." ${ }^{67}$ His justification was that giving the jury a context without opening up facts and second-guessing the verdicts of the first jury would do justice.

I also consider that justice is served in this way - if, in fact, it is necessary to give the jury a context. There is no particular reason, however, that the prosecution would require such a context to be provided. Further, the main reasons the defence would like the jury to know of the previous acquittals are either to indicate that the complainant was not believed by another jury and/or that the defendant is innocent of Count 12 as he was innocent of the other 11 counts. Both these grounds for admission were, however, rejected by Baragwanath $\mathrm{J}$.

Despite the decision in $R v B$, the law relating to admission of evidence of a previous acquittal, when offered by the defendant in a criminal trial remained unclear as a matter of practice. There is

$65 R v B$, above, 9.

$66 R v H(1990) 90$ Cr App R 440, 445 (CA) Lord Lane CJ for the Court.

$67 R v B$, above, 10. 
certainly no general rule of exclusion and in certain circumstances it is clear that as a matter of policy the defence should be entitled to offer such evidence as part of the defence case. Whether in fact a defendant can offer such evidence which is both sufficiently relevant and which does not raise concerns of time wasting or distraction remains to be seen. In $R v$ Arbuckle the Court of Appeal was also concerned that trying to explain the proper use of the evidence to the jury would raise the significant (and undesirable) prospect of a mistrial (this, it must be said, in a case where the prosecution sought to offer the evidence of previous acquittals). ${ }^{68}$

Post-Degnan, the Court of Appeal has had an opportunity to consider issues similar to those raised in $R \vee B$ : to what extent should a jury know about previous acquittals when deciding a remaining charge during a re-trial? In $R v B$ the defence was aware of the risk of prejudice once the jury knew it was a re-trial. Baragwanath $\mathrm{J}$ agreed that the jury should know of the acquittals as well as some of the reasons the first jury could not reach a verdict on the charge for which the defendant was being retried. In $\mathrm{Sami}^{69}$ the Court of Appeal, seemingly in agreement with this approach, although without reference to $R v B$, allowed an appeal because the jury had not been so advised. I discuss this case at some length because its ultimate resolution demonstrates the unfortunate impact unresolved admissibility rules have on all participants in the criminal justice system.

\section{B A Post-Degnan Response}

At the first trial the accused Latchman Sami had been acquitted on two counts of sexually violating and indecently assaulting the complainant, a waitress in his central city restaurant. The jury was unable to agree on the third count, an allegation of sexual violation by rape. Prior to the re-trial of the third count, the defendant applied to be discharged under section 347 of the Crimes Act 1961 on the basis that a discharge would be consistent with the other two not guilty verdicts, in other words the discharge would avoid an inconsistent guilty verdict. Counsel for the defendant also argued, of relevance to this discussion, that the jury at the second trial would have to revisit an issue of fact decided in the first trial "and be called on to come to the opposite conclusion ... that can be a collateral attack on the decision of the first jury". ${ }^{70}$

In relation to the inconsistency verdict, Judge Keane held, accepting the Crown's arguments, that the "jury had two readily apparent reasons on the evidence for distinguishing the third count from the other two". ${ }^{71}$ The first reason was that after the first two incidents the complainant did not tell anyone nor did she cease to work for Sami. After the alleged rape however, she told friends and her

$68 R v B$, above, 5 .

$69 R v$ Sami (1 May 2001) Court of Appeal CA 126/01 Keith J for the Court.

$70 R v$ Sami [2000] DCR 847, 851 Judge Keane.

$71 R v$ Sami, above, 852. 
doctor and did leave her job. Judge Keane also pointed to the medical evidence offered in support of the third count that was not relevant to counts one and two.

The District Court judgment also considers the validity of the jury in the re-trial reviewing what the first jury had resolved, especially with regard to the defence of consent. John Billington QC argued that if Sami had been convicted of the first two counts, the evidence (and result) relating to those charges may have been admissible under the similar fact rule. ${ }^{72}$ Degnan (decided after the District Court hearing in Sami) of course extended this rule to include offering evidence that has resulted in acquittals. The defence then surprisingly stated that in this context it would not be open to them "to disclose to the jury that the accused was acquitted". ${ }^{73}$ In Sami, as in $R v B$, the defence actually wished to rely on the evidence leading to the previous acquittals to strengthen their case relating to the defence of consent. In Sami Billington QC argued that the defence would have to: ${ }^{74}$

lead evidence that relations were consensual from the first, identifying those earlier occasions as instances ... [and] to find the accused guilty of the third count the jury would have to accept [the complainant] as credible. On that central issue it would have to differ from the first jury.

This process, it was claimed, would result in a miscarriage of justice.

The defence's argument on this point was, to be fair, made in the context of a section 347 discharge application and, as such, relied on a view of the previous verdicts as correct and operating as both synonymous with the accused's innocence and the complainant's lack of credibility. An acquittal, to repeat the Court of Appeal's view in Degnan, can also result from insufficient evidence to discharge the prosecution's standard of proof. As in $R v B$, when there are explanations for different verdicts, it is more likely to be the case that the acquittal has resulted from the standard not being met, rather than because the complainant was lying or mistaken or just not believed. As Paul Roberts points out: ${ }^{75}$

The procedural significance of an acquittal, I suggest, stops short of interfering with a rational appraisal of the totality of the evidence in subsequent proceedings. A court trying fresh charges in relation to conduct which has never before been the subject of criminal proceedings should be free to depart from findings of fact made in earlier trials, and may do so without ever questioning the legal validity of a previous acquittal or tolerating abuse of its process.

$72 R$ v Sami, above, 852.

$73 R v$ Sami, above, 852.

$74 R v$ Sami, above, 852 .

75 Paul Roberts "Acquitted Misconduct Evidence and Double Jeopardy Principles, From Sambasivam to $Z$ " [2000] Crim LR 952, 958-959. 
In Sami, Judge Keane did not accept the defendant's submissions concerning revisiting the consent issue but seemingly not for reasons similar to those proposed by Roberts. The Judge was of the view that there would be no need to revisit the previous acquittals as a matter of procedure in the retrial. He accepted that the Crown would limit the evidence lead on the third count so that the jury would only be aware of the earlier counts (acquittals) if the defence elected to mention them. The Judge concluded: ${ }^{76}$

I do not see that the defence needs to raise those incidents to ensure that the accused obtains a fair trial, the final focus of which must be on the ultimate incident. Nor can I see that the defence will gain any significant advantage by doing so. The two earlier incidents can be no more than instances of the defence case, that relations were consensual from the first. In reply the Crown can raise the contrasts outlined earlier, and the Judge will likely have to remind the jury to focus on the single count before it, and the related evidence.

The accused may well do better if the jury became aware of the full ambit of the first trial and the acquittals. But the Crown's response will be the same; and the Judge will likely have to direct the jury not to speculate about why the first jury found as it did, and, as before, to focus on the evidence directly related to the single count it is considering.

These statements are consistent with the conclusion reached by Baragwanath $\mathrm{J}$ in $R v B$ except that in the earlier case Baragwanath $\mathrm{J}$ prevented speculation by giving the jury information concerning the deliberations of the first jury. It was very unfortunate for the complainant in Sami, who as a result of the successful appeal would have been required to give evidence for a third time, had she been willing to do so, ${ }^{77}$ that the jury were not made aware of "the full ambit of the first trial and the acquittals". ${ }^{78}$ The Court of Appeal held the jury should have been told of the previous acquittals because of what had emerged from the evidence of the complainant.

On two occasions during the retrial, cross-examination of the complainant included references by the defence to her evidence at the previous trial. After the first occasion, the Judge answered a question from the jury in the following way: ${ }^{79}$

Madam Foreman, members of the jury, before we resume the evidence this afternoon I understand you have raised a question about why we have a retrial which obviously we have. At this stage I would simply ask you not to speculate about the reasons, I will direct you on the issue of the retrial later on, but at this stage if you would simply concentrate on the evidence in this trial and we will come back to the issue later.

$76 R v$ Sami, above, 853.

77 "Restaurateur Walks Free - Woman Won't Testify Again" (25 July 2001) The Evening Post Wellington 3.

78 As recommended by Judge Keane in the District Court: $R v$ Sami, above, 853.

$79 R v \operatorname{Sami}$ (1 May 2001) Court of Appeal CA 126/01, Keith J, 4. 
At the conclusion of the second exchange, the defence elected not to go on and ask the complainant whether the defendant has been acquitted of the charges leading from the incidents explored in cross-examination. This was despite the fact that the complainant had at first denied the earlier incidents "because the Crown prosecutor had directed her not to mention the two events that were the subject of the earlier acquittals". 80

At the conclusion of the cross-examination of the complainant, counsel met with the Judge in chambers. At this time the Crown opposed any mention to the jury of the earlier acquittal as part of the jury directions and neither counsel advised the trial Judge of the statement made by Judge Keane at the end of his decision on the section 347 application. Instead the Judge on retrial made the following statements as part of the summing up: ${ }^{81}$

It is no secret that there was a retrial in this case, but I simply say to you in that regard do not speculate about what may have happened at the earlier trial or why there was a retrial. Your task is to focus on the evidence that you have heard in this trial and make your decision on the basis of that evidence.

After traversing these matters, the Court of Appeal held there was a miscarriage of justice because the jury may have had the wrong impression "that the appellant had been convicted at the earlier trial of the counts relating to the other two incidents". ${ }^{82}$ The Court went onto hold that ${ }^{83}$

[i]n the circumstances of [the] case, the jury should have been told of the actual result of the earlier trial while being directed that they were to decide the present count on the evidence before them. Because they may well have had the wrong - and wrongly prejudicial - impression about what had happened, we find that there was a miscarriage of justice.

This result was wholly avoidable. Despite the existence of earlier clear advice given by Judge Keane (and the good practice followed by Baragwanath $\mathrm{J}$ in $R v B$ ), the judge in the retrial received no assistance from the prosecution or defence to formulate directions to overcome the prejudicial impression created by their unnecessary subterfuge. The process of the trial and the successful appeal illustrates the need to avoid misleading the jury by "hiding" relevant evidence.

The Court of Appeal in Sami, although indicating the desirability of letting the jury know about the previous acquittals (interestingly, without any reference to $R v B$ ), does not offer much assistance with regard to the admissibility of evidence of acquittals. The only mention of Degnan follows the quote from the defence in the District Court to the effect that the defence could not "disclose to the jury that the accused was acquitted". Keith J, delivering the judgment for the Court

$80 R v$ Sami, above, 4.

$81 R v$ Sami, above, 5-6.

$82 R v$ Sami, above, 6.

$83 R v$ Sami, above, 6. 
of Appeal, records a comment in parentheses: "On evidence being led about acquittals see now $R v$ Degnan CA347/00". ${ }^{84}$ This aside is unsatisfactory in that it indicates (erroneously) that Degnan provides guidance on the issues raised by the defence in the District Court.

In a further statement, the Court of Appeal adds to the confusion by accepting the Crown's argument that "the fact of an acquittal is not in general admissible evidence". ${ }^{85}$ This is an unexpected acceptance of a statement at odds with Degnan (previously cited by the Court) and a rule which would operate to deprive defendants of evidence to support their defence.

There may well be room for a different approach when the defendant offers evidence of an acquittal, as compared to similar fact evidence offered by the prosecution - indeed this will be my argument in the next section - but this distinction is not drawn out in Degnan or Sami. Degnan leaves unanswered how evidence of previous acquittals may be used by the defence. The concerns raised by the defence in Sami and by Baragwanath $\mathrm{J}$ in $R v B$ about the dangers of unnecessarily revisiting significant portions of previous trials were not adequately addressed in Degnan, despite the fact that the arguments were made and recorded before the Court heard the appeal in Degnan.

\section{TOWARD ADMISSIBILITY RULES WHICH DO NOT OFFEND}

My consideration of the issues surrounding the admissibility of evidence of acquittals in criminal proceedings will conclude by beginning to formulate answers to the following questions:

(1) When, as part of the similar fact rule, should evidence from a previous trial which has resulted in an acquittal, be admissible for the prosecution in a later trial (including a retrial)?

(2) Are there any other circumstances in which the prosecution should be permitted to offer evidence of a defendant's earlier acquittal or of the evidence on which it was based?

(3) When should a defendant in a criminal trial be permitted to offer evidence of an acquittal or of the evidence on which it was based?

As will be apparent from the preceding discussion, a single rule of evidence cannot sensibly answer each of the questions posed, except at the level of broad principle. There are clearly different policy considerations which must be recognised in making various admissibility decisions. To rigidly apply only one rule will not allow appropriate recognition of policies which will be in conflict. The Court of Appeal's attempt in Degnan to resolve the admissibility issues only at the level of broad principle without reference to necessary exceptions has resulted in confusion and may result in injustice. My proposed resolution of the issues will similarly begin with a broad

$84 R$ R Sami, above, 2.

$85 R v$ Sami, above, 6. 
admissibility rule but will also consider some exceptions and practical details in response to each of the questions posed, as well as discussing the desirable scope of a discretionary exclusion.

\section{A The General Rule of Admissibility: Adapting the Proposed Evidence Code}

Evidence of prior acquittals, and evidence leading to prior acquittals, if relevant, should be admissible in a criminal trial (whether offered by the prosecution or the defence) unless excluded by some rule of law or by judicial discretion. This is true for all items of evidence and, as stated in Degnan, is the appropriate "starting point on all admissibility questions". ${ }^{86}$

One general exclusionary rule should also apply to all admissibility decisions, whether or not other rules are satisfied. This rule is usually stated under common law as one of exclusion of evidence on the grounds of unfairness or illegality. In most contexts, I prefer the Law Commission's proposed section 8 exclusionary discretion as it encourages the court to prevent the "needless repetition" of evidence and recognises the importance of the defendant's ability to offer an "effective defence" (section 8(2)). Both these inquiries are significant in the context of acquittal evidence and should be considered even after other specific admissibility rules (for example, the rules relating to propensity evidence) are satisfied. However, it is specifically in the context of the similar fact rules that section 8 as currently drafted may not operate effectively to regulate the admission of similar fact evidence that has resulted in a previous acquittal.

The similar fact rule codified in section 45 of the proposed Evidence Code (entitled "Propensity evidence offered by prosecution about defendants") includes the requirement that the evidence "has a probative value ... which clearly outweighs the risk that the evidence may have an unfairly prejudicial effect on the defendant." 87 Although the rule refers to "unfair" prejudice, the Code's guidance to the judge on how to consider prejudicial effect does not mention the risks of relitigation or double jeopardy (see section 45(4)). Similarly, the general exclusion in section 8 refers to "unfairly prejudicial effect". If similar fact evidence which has lead to an acquittal passes the admissibility test under section 45 of the Code, it is arguable that there is no general discretionary exclusion on the grounds of "unfairness" in the Code (because the Code's inquiry is the same in both the similar fact rule and the general discretion). ${ }^{88} \mathrm{~A}$ general unfairness discretion may well be preserved by section 11 of the Code (preservation of inherent powers) but it seems preferable to have a general exclusion which actually incorporates all the relevant considerations. It may be that under the Code, the admissibility decision under section 45 will incorporate the unfairness inquiry

$86 \quad R v$ Degnan [2001] 1 NZLR 280, 285 (CA) Tipping J for the Court.

87 The New Zealand Law Commission Evidence: Evidence Code and Commentary (NZLC, R 55, Vol 2, Wellington, 1999) 120, section 45(1)(b).

88 For a good discussion of the sustainability of the two similar tests, see Don L Mathieson (ed) Cross on Evidence (7 ed, Butterworths, Wellington, 2001) para 13.24. 
which is currently preserved as the "second condition" of admissibility (at least according to Wilson $)^{89}$ - but the Code does not make this clear.

My recommendation is that section 8 of the proposed Evidence Code should be re-drafted to include reference to a general discretion to exclude on the grounds of unfairness. This is one way in which the two-stage test (which I go onto to suggest should be preserved at common law) can be clearly incorporated into the Code. Such a two-stage test can allow an inquiry into whether there has been an abuse of process (for example, the extent to which the admission of the evidence amounts to a re-litigation of a previous charge). The practical application of this inquiry is discussed in more detail in Part B below.

\section{B Specific Admissibility Rules and Procedures: Clarifying the Common Law Position}

\section{Similar fact evidence}

Similar fact evidence offered by the prosecution which has previously resulted in an acquittal rather than a conviction may be admissible in the subsequent trial, or re-trial, of a defendant. In Degnan the Court of Appeal's only limitations on the general admissibility rule in these situations were either when the admission would be "unfair to the accused"90 - "there must always be a reserve power to exclude the evidence, if in the particular circumstances it would not be fair to the accused to admit it"91 or "would otherwise result in an abuse of process". 92 The Court approved the alibi example given in $R v Z$ as an example of unfairness which should result in the evidence being excluded. ${ }^{93}$

Given that the alibi example is an example of "unfairness", in what other situations under Degnan as currently formulated, should acquittal evidence be excluded? My previously stated interpretation of the alibi example is that if the evidence re-opens an issue that has clearly been previously decided (by another jury) it would be unfair to admit the evidence. Unfortunately, if this interpretation is correct - the fairness discretion should have applied in favour of the defendant in Degnan. As Mahoney argues: ${ }^{94}$

[I]n admitting th[e] similar fact evidence in Degnan despite the acquittal (and the stay of proceedings), the Court was necessarily accepting that the evidence would go to prove the current charge of indecent assault. The only possible way in which that process could occur is by the current jury concluding that

$89 R v$ Wilson [1997] 2 NZLR 161, 166 (CA) Eichelbaum CJ for the Court.

$90 R v$ Degnan [2001] 1 NZLR 280, 291 (CA) Tipping J for the Court.

$91 \quad R v$ Degnan, above, 291.

$92 R v$ Degnan, above, 292.

$93 R v$ Degnan, above, 291.

94 Richard Mahoney "Evidence" [2002] NZ Law Rev 101, 114-115. 
the accused had indeed committed the offence for which he had earlier been acquitted, thereby making a finding (in the words of Gee ...) "in conflict with that of the first jury ... [N] either Lord Hobhouse nor the Court in Gee offers any explanation why it is acceptable to ask a second jury to contradict the first when the issue is whether any offence occurred, but not when the issue is the identity of the offender. This is not surprising, because no explanation exists.

It seems then that Degnan as argued provides no actual examples of when acquittal evidence should be excluded and, as such, the discretion to exclude on the grounds of unfairness has no real substance, given that it does not operate to prevent re-litigation of previously settled verdicts. Although an unfairness discretion can and should operate to prevent injustice, it seems clear that the Court of Appeal needs to provide more direction as to when it should operate in this context. In the words of Eichelbaum CJ in delivering the judgment for the Court of Appeal in Wilson: "the challenge is to find some principled basis for deciding what is not unfair in particular circumstances". 95

I agree with Mahoney that the necessary starting point to develop a relevant "jurisprudence on unfairness" is to return to the pre-Degnan/Wilson position. He argues that: ${ }^{96}$

there should be a strict limitation on the occasions when the Crown can allege that the accused was involved in an occurrence that has formed the basis of a charge for which the accused has earlier been acquitted. The Crown should only be permitted to take this position when it can coherently be accepted that some, but not all, of the elements of the offence for which the accused was acquitted were present.

If this is a return to a rule "such as that which distinguishes between evidence proving guilt of the earlier allegation and evidence tending to prove such guilt", 97 a distinction rejected in Degnan as unsatisfactory, then so be it. What is important is that the case law provides appropriate guidance for trial judges to be able to apply and rely on the unfairness discretion in appropriate cases. Given that the result of Degnan is itself more than just "unsatisfactory", a return to a rule which provides a principled, if conservative, approach is to be preferred. As I stated in the introduction - the development of the rule requires "careful development" - a return to the previous case law will, I believe, give the Court of Appeal the opportunity for such careful development.

It is important to note, although not raised on the facts of Degnan, that the admissibility rule proposed should also apply in the case of re-trials, such as Gee. The argument for such an application is well made by Diane Birch. ${ }^{98}$ In her commentary she gives a hypothetical example that

$95 R v$ Wilson [1997] 2 NZLR 161, 167 (CA) Eichelbaum CJ for the Court.

96 Mahoney, above, 115.

$97 R v$ Degnan [2001] 1 NZLR 280, 291 (CA) Tipping J for the Court.

98 Diane Birch"R v Z" [2001] Crim LR 222. 
she considers should be an exception to $R v Z$ : a retrial of one count when the defendant has been found not guilty of the first two counts. She then poses the following questions: ${ }^{99}$

At a retrial, may the prosecution call A and B to give the same evidence as before? Presumably, if the acquittals do not show that $\mathrm{D}$ did not commit those two crimes, the evidence of $\mathrm{A}$ and $\mathrm{B}$ still has the requisite degree of probative value in relation to $\mathrm{C}$ 's case. Nothing has changed except that the jury $t$ the second trial cannot obviously convict in respect of A and B. But surely it is precisely because nothing has changed since the acquittals that it would be unfair for the prosecution to rely on the same evidence again.

In the context of a re-trial, this is an example of where the discretion to exclude on the ground of unfairness should apply.

\section{Evidence leading to an acquittal offered by the prosecution for other reasons}

There is little relevant New Zealand case law on the point, but it is not hard to think of situations in which the prosecution may wish to offer evidence which led to an acquittal in an earlier trial. Such situations include the trial of another defendant accused of the same offence, either because the first accused was mistakenly charged or because they are co-accused being tried separately. In these situations the general admissibility rule outlined above would apply.

It is harder to think of realistic examples where the prosecution would wish to offer evidence concerning an accused (which led to an acquittal) in a subsequent trial of that accused, and the evidence was not being offered as character or propensity evidence. If such a situation did arise, judges should be inclined to carefully consider the admissibility issue if there is any risk that the jury may misuse the evidence.

In the case of Arbuckle, ${ }^{100}$ the prosecution argued that the evidence leading to the acquittals should be offered as part of the Crown case to establish the mens rea of the charge (fraudulent intent). ${ }^{101}$ Although the Court did not view this argument as giving rise to admission of similar fact evidence, such evidence would clearly be caught by that rule under the Evidence Code (see in particular the definition of propensity evidence in section 4). ${ }^{102}$ In any event, however the argument is put, evidence which invites the jury to reconsider the validity of a previous acquittal should be excluded - pursuant to the application of the fairness discretion outlined in the previous section. In

99 Birch, above, 224.

$100 R v$ Arbuckle [2000] 3 NZLR 49 (CA) Keith J for the Court.

$101 R v$ Arbuckle, above, 53.

102 This definition provides that "propensity evidence means evidence of ... acts ... with which a person is alleged to have been involved which tends to show that person's propensity ... to have a particular state of mind". The New Zealand Law Commission Evidence: Evidence Code and Commentary (NZLC, R 55, Vol 2, Wellington, 1999) 18. 
the case of Arbuckle (as to this point), the Court of Appeal accepted that the only defence available to the accused was lack of the required dishonest intent. ${ }^{103}$ Given that the prosecution wished to offer the evidence from the previous trial in order to establish fraudulent intent, the Court was right to be concerned that this would put in question the acquittals. ${ }^{104}$

\section{Evidence leading to an acquittal offered by an accused}

In principle, there is no reason why evidence leading to an acquittal or evidence of an acquittal should not be offered by a defendant as long as it satisfies the general admissibility rule. This should be the case when it is offered in response or in rebuttal to similar fact evidence offered by the prosecution.

Paul Roberts asks whether a defendant in a case like $R v Z$ should be "permitted to tell the jury that he has already been acquitted of three of the incidents which the prosecution now cites of a pattern of conduct proving his guilt of the present charge?" His answer: "It is submitted that he should. Defendants should in principle always be able to tell the jury about a relevant previous verdict bearing on the issues in the current trial." 105

Roberts notes that such an approach, while not in keeping with the traditional rules of evidence, "can be seen to promote both fairness to the defendant and effective fact-finding, by supplying the jury with pertinent additional information to complete the 'bigger picture' of the events under investigation". 106

The difficulties which may arise in completing the "bigger picture" are those discussed by Baragwanath $\mathrm{J}$ in $R v B$ : that of (time-wasting) re-litigation of the previous case and the potential for the jury to get side-tracked on pre-determined issues. Appropriate jury directions can at least address the second of these issues, as was the case in $R v B$.

What of the position of defendants who wish to offer evidence of another person's acquittal (for example, the acquittal of a co-defendant for the same charge in a previous trial)? The existing authority on this point is Hui Chi-ming $v R^{107}$ in which the Privy Council agreed that the appellant was not entitled to offer evidence of the principal's offender's acquittal for murder. The Council's advice was that the acquittal "amounted to no more [than] the opinion of that jury". ${ }^{108}$

$103 R v$ Arbuckle, above, 52.

$104 R v$ Arbuckle, above, 54.

105 Paul Roberts "Acquitted Misconduct Evidence and Double Jeopardy Principles, From Sambasivam to Z" [2000] Crim LR 952, 966.

106 Roberts, above, 967.

107 Hui Chi-ming v R [1992] 1 AC 34 (PC) Lord Lowry for the Council.

108 Hui Chi-ming v R, above, 43 
As the Law Commission states in Evidence: Report 55, Volume One: ${ }^{109}$

Such a rigid approach may operate to the defendant's extreme disadvantage. In the Commission's view, there is merit in making the acquittal admissible in evidence ... Admitting the acquittal may give the court the opportunity to hear argument on and take into account the facts leading to the acquittal if they are of significance.

While I agree with the Commission's response to the authority of Hiu Chi-ming, an approach which allows the court to "hear argument on ... the facts leading to the acquittal" must be tempered by further guidance, if the concerns about re-litigation are to be addressed.

Although there is less concern about re-litigation and consequential unfairness when the evidence giving rise to the acquittal relates to another accused, it may be the case that evidence offered in the defence of the co-accused may incriminate the accused who wishes to offer the evidence of the acquittal. In such a situation, the same careful inquiry into fairness issues must apply. It is clear that any evidence offered in the previous trial which related to the case against the accused cannot form part of the evidence in a later case only by reason of the defendant's wish to offer evidence of the earlier acquittal. The general admissibility rule must, in such a case, be carefully employed to appropriately balance prejudicial effect and probative value - taking into account the defendant's right to mount a full defence. In this situation too, it is clear that the Court of Appeal must take the next

\section{CONCLUSION}

Recent case law dealing with the admissibility of evidence which has previously resulted in an acquittal, including evidence of the fact of an acquittal, has resulted in rulings which are either too broad or too particular.

In relation to the admission of similar fact evidence, when that evidence has previously formed the basis of a charge which has resulted in an acquittal, the Court of Appeal decision in Degnan laid down a broad admissibility rule which appeared to allow unlimited re-litigation of previous verdicts, despite clear principles to the contrary. Although the decision has been partially resiled from in Gee, the Court of Appeal has yet to posit a workable and justified admissibility rule in this area.

Courts must therefore find "some principled basis" for applying the fairness discretion preserved in both those cases. Cases decided on such a principled basis include those seemingly rejected by the Court of Appeal in Degnan - cases which "analogise the closely related double jeopardy cases"110 and offer appropriate protection to an accused. The decisions of cases like Wilson should instead be preferred.

109 New Zealand Law Commission Evidence: Reform of the Law (NZLC R55, Vol 1, Wellington, 1999$) 67$.

$110 R v$ Wilson [1997] 2 NZLR 161, 167 (CA) Eichelbaum CJ for the Court. 
Similarly, the Court of Appeal needs to offer trial judges more guidance on the appropriate evidential and procedural rules in cases when the defendant wishes to offer evidence of previous acquittals. The recent case of Sami illustrates the importance of all parties in a criminal trial to have a clear understanding of the proper use which may be made of previous acquittals. In this area too, broadly stated exclusionary rules must be avoided. ${ }^{111}$ A fair, pragmatic approach must be embraced which will best serve our criminal justice system.

Finally, the proposed Evidence Code needs amendment in order to appropriately accommodate the developing common law in these areas. The Code's "first principles" approach to admissibility (which renders admissible all relevant evidence) ${ }^{112}$ is positive and flexible but also lacks the kind of specific guidance which may be helpful to trial judges. In particular, the explicit preservation of a fairness discretion seems advisable, along with examples of the situations in which such a discretion should be exercised, particularly with regard to similar fact evidence.

$111 R v$ Sami (1 May 2001) Court of Appeal CA 126/01, 5, Keith J for the Court.

112 See section 7 of the proposed Evidence Code: The New Zealand Law Commission Evidence: Evidence Code and Commentary (NZLC, R 55, Vol 2, Wellington, 1999) 30. 
